Debreceni Egyetem, Fogorvostudományi Kar, Fogpótlástani és Bioanyagtani Tanszék*

Debreceni Egyetem, Általános Orvostudományi Kar, Biofizikai és Sejtbiológiai Intézet ${ }^{\star *}$

Debreceni Egyetem, Fogorvostudományi Kar, Gyermekfogászati és Fogszabályozási Tanszék ${ }^{\star \star \star}$

Debreceni Egyetem, Fogorvostudományi Kar, Konzerváló Fogászati Tanszék ${ }^{* \star * \star}$

Semmelweis Egyetem, Fogorvostudományi Kar, Orálbiológiai Tanszék ${ }^{\star \star \star \star \star}$

\title{
Fogbél eredetű őssejtek fluoreszcens és mágneses válogatásának összehasonlító vizsgálata
}

\author{
KERÉNYI FARKAS*, TARAPCSÁK SZABOLCS**, DR. HRUBI EDIT*, \\ BARÁTHNÉ SZABÓ ÁGNES*, DR. HEGEDÜS VIKTÓRIA**, DR. BALOGH SÁRA*, \\ DR. BÁGYI KINGA ${ }^{* * *}$, DR. VARGA GÁBOR ${ }^{\star * * * *}$, DR. HEGEDÜS CSABA*
}

\begin{abstract}
Munkánk során humán bölcsességfog pulpájából izoláltunk őssejteket. A pulpából származó heterogén sejtpopulációból ezeket az őssejteket fluoreszcensen vagy mágnesesen jelölt, valamilyen őssejt specifikus sejtfelszíni marker ellen termeltetett ellenanyaggal lehet kiválogatni. Munkánk célja az volt, hogy a fluoreszcens (fluorescent activated cell sorting FACS) és a mágneses (magnetic activated cell sorting - MACS) sejtszeparálást összehasonlítsuk hatékonyságuk és a sejtekre gyakorolt hatásaik alapján. Eredményeink azt mutatták, hogy a válogatás hatékonysága hasonló (MACS 79,53 $\pm 5,78 \%$, FACS $88,27 \pm 3,70 \%$ ) mindkét általunk használt módszer esetén, a MACS azonban sokkal kíméletesebbnek bizonyult, az abból származó sejtpopulációk gyorsabban növekedtek.
\end{abstract}

Kulcsszavak: DPSC, FACS, MACS

\section{Bevezetés}

Az őssejt kifejezést Ernst Haeckel vezette be, és az összes élólény közös ősét jelentette [9]. Később kibővítette értelmét arra a sejtre is, amelyikből szervezetünk összes sejtje származik: a megtermékenyített petesejtre [8]. Ma olyan sejteket értünk alatta, melyek különlegessége, hogy aszimmetrikus mitotikus sejtosztódással képesek önmagukat megújítani és a szervezet speciális funkciót ellátó testi sejtjeivé differenciálódni [14]. Ilyen őssejtek a legtöbb, ha nem az összes többsejtủ élőlényben megtalálhatók. Az emlősök őssejtjei két fő típusra oszthatók: az embrionális őssejtek a blasztocisztákban (hólyagcsíra állapotban lévő embrió), a felnőtt őssejtek (vagy szöveti őssejtek) pedig a felnőtt szövetekben találhatók meg. A fejlődő embrióban az őssejtek az öszszes specializált magzati szövetté képesek átalakulni. A felnőtt szervezetben az őssejtek és az előd (progenitor) sejtek a test javító mechanizmusaként szolgálnak, a specializált sejteket felfrissítve, ugyanakkor a folyamatosan megújuló szerveknek - mint a vér, bőr vagy az emésztőrendszer szövetei - normális megújulásában is közremüködnek [1]. A mai molekuláris biológiai módszerek lehetőséget adnak arra, hogy sejtkultúrában tenyésztett őssejteket különböző szövettípusoknak (izmok, idegek) megfelelő specializált sejtekké transzformáljunk, ezért a kutatások egyre inkább a terápiás felhasználás lehetőségeit keresik.
Őssejteket bárhol találhatunk testünkben, így szájüregünk különböző szöveteiben is (összefoglalva: [4]). Fogbélből először Gronthos és mtsai izoláltak őssejteket 2000-ben [7]. A fogbél eredetű őssejtek (dental pulp stem cells - DPSC) egyik előnye, hogy egyébként is eltávolításra kerülő bölcsességfogakból könnyen kinyerhetők, így az őssejtek izoláláshoz nincs szükség külön beavatkozásokra. A másik, hogy számos irányba differenciáltathatók, ennek megfelelően a terápiás felhasználás lehetőségei is szinte korlátlanok (összefoglalva: [3]).

A fogbélben azonban kevert sejtpopuláció található, ebből kell kinyernünk az őssejteket. Ezt őssejt specifikus sejtfelszíni fehérjék ellen termeltetett ellenanyagok segítségével tehetjük meg. Ha ezeket az ellenanyagokat fluoreszcensen vagy mágnesesen jelöljük, akkor különböző módszerekkel a jelölt sejtek, melyek kifejezik felszínükön a specifikus sejtfelszíni fehérjét, izolálhatóvá válnak. Az egyik ilyen, fogbél eredetű őssejtekre jellemző fehérje a STRO-1 [10].

Fluoreszcens molekulával kapcsolt ellenanyaggal jelölt sejtek szeparálására áramlási citométert használhatunk (Fluorescence Activated Cell Sorting - FACS) [2], ami adott hullámhosszúságú lézer segítségével detektálja a fluoreszcensen jelölt sejteket. Ha a lézer útját fluoreszcensen jelölt sejt keresztezi, azt töltéssel látja el, ez alapján különíti el a jelölt sejteket a jelöletlen (és így töltés nélküli) sejtektől. 
Mágneses mikrogyönggyel kapcsolt ellenanyaggal jelölt sejteket mágneses oszlopon izolálhatjuk (Magnetic Activated Cell Sorting - MACS) [12]. Ebben az esetben egy erős mágnesre helyezett mágnesezhető oszlopra visszük föl a sejtszuszpenziót. A jelölt sejtek az oszlopon kitapadnak, míg a jelöletlenek lemoshatók. Az oszlopot eltávolítva a mágnesről, mágnesesség hiányában a jelölt sejtek is lemoshatóvá válnak az oszlopról.

Munkánk célja az volt, hogy bölcsességfog pulpájából életképes primer STRO-1 pozitív őssejteket izoláljunk, valamint összehasonlítsuk az izolálásra használható, irodalomból ismert két módszer (MACS, FACS) hatását a sejtekre.

\section{Vizsgálati anyagok és módszerek}

\section{Szövetminták}

Munkánkhoz a Debreceni Egyetem Fogorvostudományi Karán ellátott páciensekből sebészi úton eltávolított, impaktált bölcsességfogakat használtunk, ügyelve arra, hogy olyan fogakat válasszunk, melyek nem közlekedtek a szájüreggel, illetve amelyek az eltávolítás alatt nem sérültek. A páciensek a Beleegyező nyilatkozat (FO321/1.C) aláirásával járultak hozzá eltávolított szöveteik felhasználásához.

\section{Sejtizolálás és sejttenyésztés}

Az irodalomban fellelhető, többféle módszer adaptálásával, kombinálásával és továbbfejlesztésével végeztük a sejtek izolálását és tenyésztését $[7,11,13]$. A bölcsességfogakat mútéti eltávolításuk után azonnal steril Hank-féle sóoldatba helyeztük. A bölcsességfogakat turbinába fogható gyémánt fisszúra fúróval vízhútés mellett hossztengelyének megfelelően szeparáltuk, ügyelve a sterilitásra, illetve a pulpakamra és a gyökércsa-

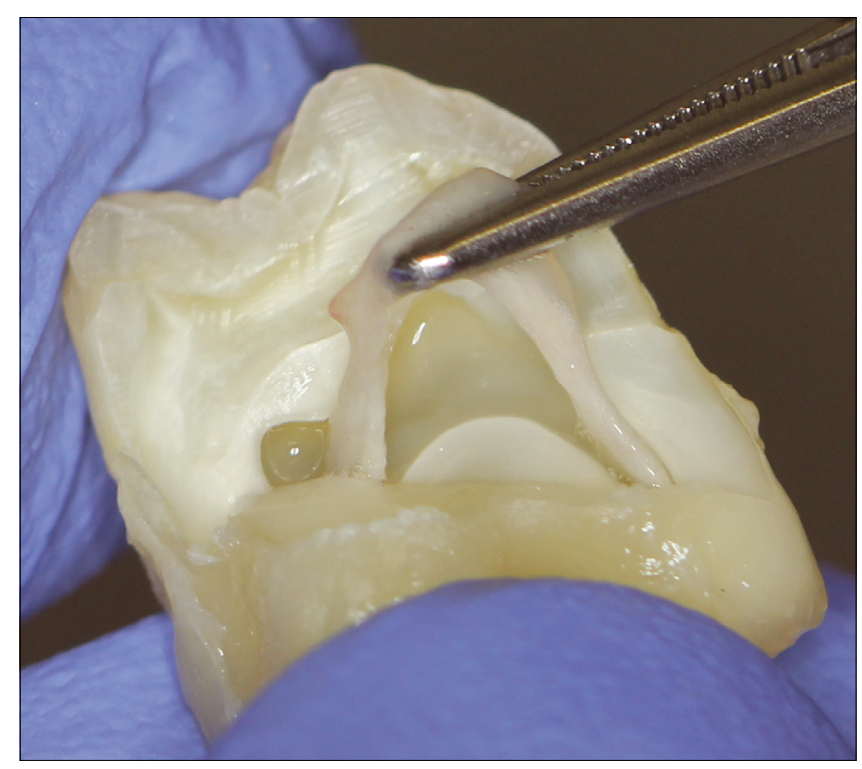

1. ábra: A pulpa eltávolítása.

A pulpát steril fülkében távolítottuk el a hosszában körbevágott, majd szétrepesztett fog pulpakamrájából. torna sértetlenségére, majd a fogakat azonnal szobahőmérsékletǔ streptomycin-penicillinnel kiegészített steril Hank-féle sóoldatba helyeztük és a laboratóriumba szállítottuk. Lamináris fülkében steril körülmények között a vágás mentén kettérepesztettük a fogakat, majd a pulpát eltávolítottuk (1. ábra). A pulpát steril szikével földaraboltuk és egy órán át emésztettük $37^{\circ} \mathrm{C}$-on, mintánként $1,5 \mathrm{ml}, 3 \mathrm{mg} / \mathrm{ml}$ kollagenáz (Sigma-Aldrich, St. Louis, MO, USA) és $4 \mathrm{mg} / \mathrm{ml}$ diszpáz (Gibco, Life Technologies, Grand Island, NY, USA) enzimet tartalmazó Hank-féle sóoldatban. A mintákat emésztés közben 1520 percenként vortexeltük, majd ezt követően 5 percig centrifugáltuk 1200 rpm-en. A felülúszót eltávolítottuk, a sejteket $10 \%$ fetal bovine serum (FBS), $1 \%$ penicillinstreptomycin (Sigma-Aldrich, St. Louis, MO, USA) és 1\% GlutaMAX (Gibco, Life Technologies, Grand Island, NY, USA) kiegészítést tartalmazó Minimum Essential Medium Eagle Alpha modification (Sigma-Aldrich, St. Louis, MO, USA) tenyésztőmédiumban szuszpendáltuk, és $25 \mathrm{~cm}^{2}$-es sejttenyésztő flaskába ültettük ki. Az izolált heterogén sejtpopulációt $37^{\circ} \mathrm{C}$-os $100 \%$-os páratartalom és $5 \%$-os $\mathrm{CO}_{2}$-tartalom mellett tenyésztettük. A sejttenyésztő médiumot hetente háromszor cseréltük.

\section{A sejtek válogatása és immuncitokémia}

A sejteket a második passzáláskor válogattuk. TripszinEDTA (Sigma-Aldrich, St. Louis, MO, USA) oldattal választottuk le a sejteket a tenyésztőedényröl, majd öt percig centrifugáltuk 1200 rpm-mel, végül 1\% HEPES, 10\% FBS tartalmú Hank-féle sóoldatban (HHF) reszuszpendáltuk. Mouse $\alpha$-STRO-1 IgM (Millipore, Billerica, MA, USA) ellenanyaggal 40 percen keresztül $4^{\circ} \mathrm{C}$-on jelöltük, majd háromszor mostuk HHF-fel. A másodlagos ellenanyagok Rat $\alpha$-mouse IgM MicroBeads (Miltenyi Biotec, Bergisch Gladbach, Németország) valamint Alexa Fluor 488 goat $\alpha$-mouse lgG, IgM $(\mathrm{H}+\mathrm{L})$ (Molecular Probes, Eugene, OR, USA) voltak, ezekkel szintén 40 percig, $4^{\circ} \mathrm{C}$-on jelöltük a sejteket. Kísérleteinkhez három, különböző páciensektől származó fogat használtunk föl. A méréseket a három biológiailag független mintán mindhárom válogatási módszerrel egy-egy alkalommal végeztük. Az elemszám így minden válogatási módszer esetében $n=3$. A MACS-hez mágnessel kapcsolt másodlagos ellenanyaggal jelölt sejteket megjelöltük fluoreszcensen jelölt másodlagos ellenanyaggal is, így három különböző csoportot vizsgáltunk: FACS, MACS és MACS-FACS. A mágneses válogatást MACS Manual Separatorral (Miltenyi Biotec, Bergisch Gladbach, Németország), a fluoreszcens válogatást BD FACS Aria III áramlási citométerrel (BD Biosciences, San Jose, $\mathrm{CA}$, USA) végeztük. A FACS válogatási kaput a csak másodlagos ellenanyaggal jelölt kontroll alapján állítottuk be. A kiválogatott STRO-1 pozitív sejteket a korábban említett médiumban és körülmények között tenyésztettük. A válogatást megelőzően és azt követően, valamint egy héttel később Bürker-kamra segítségével határoztuk meg a sejtek számát.

A válogatott sejtek karakterizálására az a-STRO-1 
ellenanyaggal történt mágneses szeparálás után a sejtek egy részét 24 lyukú plétbe helyeztük (30000/lyuk) és mezenchimális ( $\alpha$-STRO-1 IgM, $\alpha$-CD44 lgG), illetve haematopoietikus őssejtekre ( $\alpha-C D 14$ és $\alpha-C D 19)$ specifikus ellenanyagokkal jelöltük a gyártó (Millipore, Billerica, MA, USA) utasításai szerint. A jelölt sejteket AxioVert A1 (Zeiss, Jena, Németország) típusú inverz fluoreszcens mikroszkóppal vizsgáltuk.

\section{Osteoblast irányú differenciálódási képesség vizsgálata}

A kiválogatott őssejtek egy részét osteoblast irányba differenciáltató, $100 \mathrm{nM}$ dexamethasont, 0,2 nM aszkorbinsavat, $10 \mathrm{mM} \beta$-glycerophosphatot (Sigma-Aldrich, St. Louis, MO, USA) tartalmazó és a már említett módon kiegészített $\alpha$-MEM médiumban tenyésztettük, majd három hét elteltével a sejtközötti állományban a kalciumlerakódást Alzarin Red S (Sigma-Aldrich, St. Louis, MO, USA) festéssel vizsgáltuk, az alábbiak szerint. A sejteket háromszor PBS-ben mostuk, majd 30 percig metanolban fixáltuk, a metanolt leszívtuk, és öt percig szárítottuk. Ezt követően 2\%-os Alizarin Red S oldattal $(\mathrm{pH} \mathrm{7,0)}$ két órán keresztül inkubáltuk. Desz- tillált vízzel háromszor mostuk, majd fényképezőgép (Canon EOS 60D) segítségével dokumentáltuk a kapott eredményt. Kontrollként kezeletlen sejteket használtunk.

\section{Eredmények}

Össejtválogatás és válogatás utáni populációméret-változás

A fogbélből kitenyésztett sejtek a szövetből származó sejtekre jellemző fibroblaszt fenotípust mutattak. A sejteket második passzáláskor jelöltük MACS-hez és FACShez is. A háromszor elvégzett válogatási kísérlet alapján a mágneses oszlop a kiindulási sejtmennyiségnek $1,2 \pm 0,2 \%$-át válogatta $\mathrm{ki}$, ami valamivel több, mint a fluoreszcensen válogatott $0,9 \pm 0,2$ százalék, de a különbség nem szignifikáns $(p \geq 0,05)$. A mágnessel már leválogatott majd fluoreszcensen újra válogatott sejtek aránya a kiindulási sejtmennyiséghez képest $0,5 \pm 0,02 \%$, a MACS és a FACS csoportokhoz képest is szignifikánsan kevesebb $(p \geq 0,05)(2$. ábra $A)$. A mintákban a válogatással feldúsított őssejtek aránya
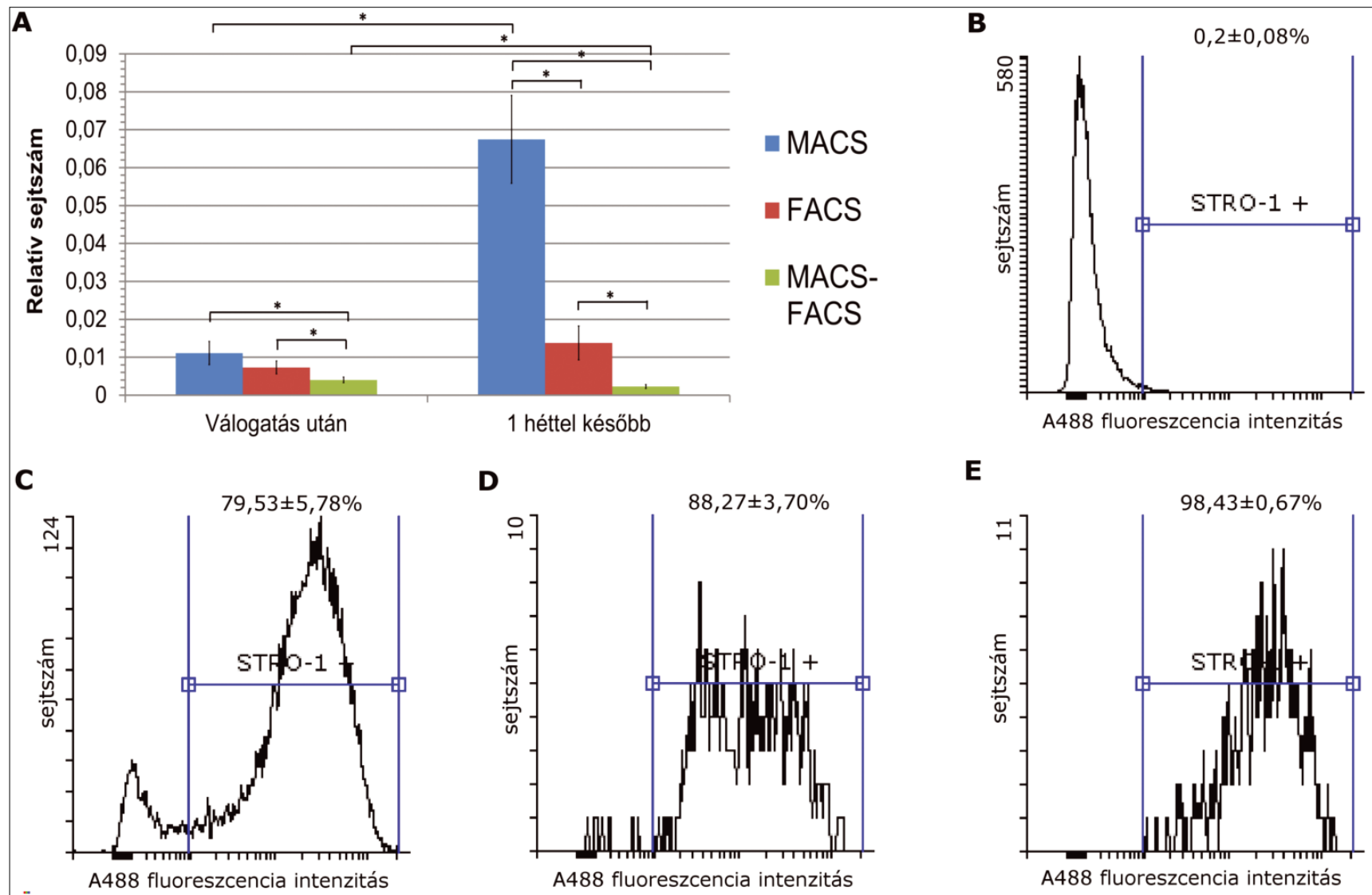

C

D

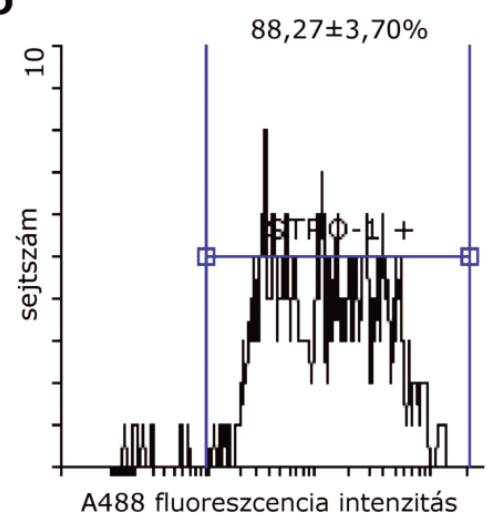

$\mathbf{E}$

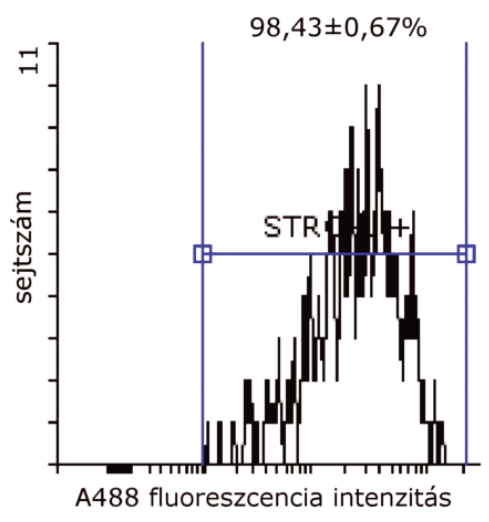

2. ábra: Az őssejtválogatás eredménye.

A) A sejtszám változása a különböző mintákban a kiindulási sejtszámhoz viszonyítva ( ${ }^{*}$ - szignifikáns különbség, $p \geq 0,05$ ). (MACS - mágnesesen válogatott csoport; FACS - fluoreszcensen válogatott csoport; MACS-FACS - mágnesesen és fluoreszcensen is válogatott csoport).

B-E) Egy-egy jellemző hisztogram a jelölt és jelöletlen sejtek fluoreszcenciaintenzitás-eloszlásáról a kontroll mintában, illetve az egyes múveletek után: csak másodlagos ellenanyaggal jelölt kontroll (B),

MACS válogatás után (C), FACS válogatás után (D), valamint MACS és FACS válogatás után (E). 

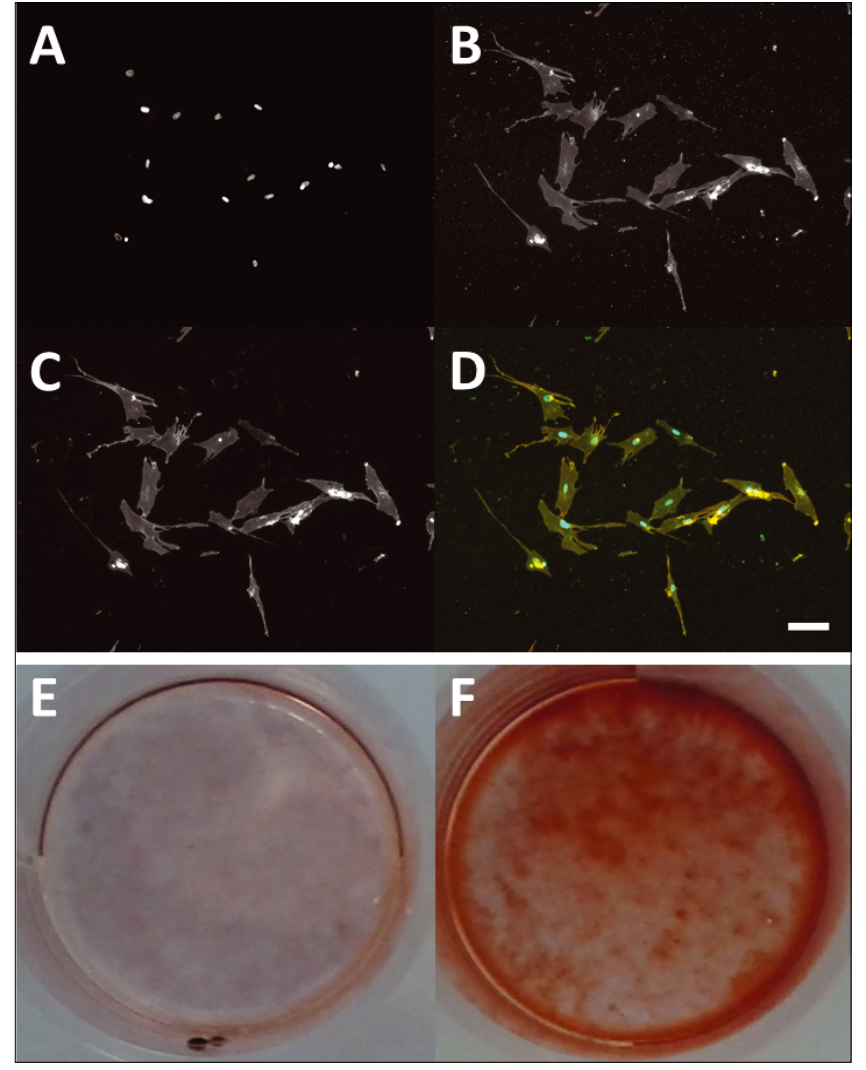

3. ábra: A leválogatott sejtek karakterizálása és osteoblast irányú differenciáltatása.

$A-D)$ Leválogatott sejtek immunofluoreszcens festés után. Sejtmag (A), a-CD44 (B), a-STRO-1 (C), egyesített (D). E-F) A sejtközötti állományban a kalcium lerakódást kimutató Alizarin Red festés tenyésztőmédiumban $(E)$ és differenciáltató médiumban $(F) 3$ hétig tenyésztett sejteken.

A pozitív festődés osteoblast irányú differenciációra utal.

a következőképpen alakult: MACS 79,53 $\pm 5,78 \%$, FACS $88,27 \pm 3,70 \%$, MACS-FACS $98,43 \pm 0,67 \%$ (2. ábra $B-E)$. A MACS és FACS válogatott mintákban az össejt-feldúsulások közötti különbség nem szignifikáns $(p \geq 0,05)$, míg a MACS-FACS válogatás során szignifikánsan nagyobb mértékben dúsultak föl az őssejtek a sejtpopulációban a MACS-hoz és a FACShoz képest is $(p \geq 0,05)$. Míg a mágneses válogatásból nyert sejtek száma egy héttel a válogatás után több mint négyszeresére nőtt, ugyanezen idő alatt a citométeres válogatásból nyerteké csak alig duplájára, de nem szignifikánsan nőtt ( $p \geq 0,05)$, míg a MACSFACS válogatásból származóké szignifikánsan csökkent $(p \geq 0,05)(2$ ábra $A)$. A FACS tehát valamelyest nagyobb tisztaságú sejtpopulációt eredményez, különösen MACS-szel kombinálva, viszont a válogatás utáni sejtpopuláció kisebb és lassabban vagy egyáltalán nem indul növekedésnek.

\section{A leválogatott sejtek tulajdonságai}

A mezenchimális őssejt markerek elleni ellenanyagokkal ( $\alpha$-STRO-1, $\alpha$-CD44) festődtek a sejtek (3. ábra A-D), míg a negatív kontrollként használt, haematopoietikus őssejtekre specifikus $\alpha-C D 14$ és $\alpha$-CD19 ellenanyagokkal nem.

A válogatott sejtpopuláció osteoblast irányú differenciálódási képességét háromhetes kezelés után vizsgálva azt tapasztaltuk, hogy a tenyésztómédiumban tartott sejttenyészetek nem, míg a differenciáltató médiumban tartott sejttenyészetek festődtek Alizarin Reddel (3. ábra E-F).

\section{Megbeszélés}

Tulajdonságaik vizsgálatához az őssejteket el kell különíteni a szöveti sejtektől. A szakirodalomban változatos módszereket alkalmaznak: szeparálják a sejteket sürüség, méret és morfológia, valamint kolonizációs képesség alapján, ám ezek a módszerek sokszor nem alkalmazhatók kellő hatékonysággal és megbízhatósággal. A sejtfelszíni fehérjék között vannak olyanok, amelyek csak bizonyos sejttípusokra jellemzőek, így vannak őssejt-specifikus sejtfelszíni markerek is. Ezek alapján általában nagy hatékonysággal és megbízható pontosságban lehet az őssejteket elkülöníteni: FACSszel körülbelül 95\% tisztaságú, MACS-szel körülbelül $75 \%$ tisztaságú sejtpopulációt lehet elérni. Ugyanakkor MACS-szel nagyságrendekkel több sejtet lehet azonos idő alatt leválogatni, mint FACS-szel $\left(\sim 10^{11}\right.$, illetve $10^{7}$ sejt óránként) [17].

A MACS nemcsak gyorsabb, hanem egyszerübb és olcsóbb eljárás, nem igényel drága műszert, hordozható, ezért gyakorlatilag bárhol használható, ahol a sejtek számára szükséges steril körülményeket biztosítani lehet. Hátránya ugyanakkor, hogy csak sejtfelszíni fehérjék alapján lehet válogatni vele [6]. Arra is vannak adatok a szakirodalomban, hogy a válogatás hatékonysága függhet a sejtek származási helyétôl és típusától, a választott sejtfelszíni markertől, illetve annak expressziós intenzitásától $[5,15,16]$.

Munkánkban összehasonlítottuk a két módszert az általunk használt sejteken. A mágneses válogatáshoz jelölt sejteket fluoreszcensen is megjelöltük, egyrészt hogy meg tudjuk mérni a mágneses válogatás hatékonyságát, másrészt hogy megvizsgáljuk, javítja-e a két módszer kombinálása (MACS-FACS) a külön-külön alkalmazott módszerek hatékonyságát. Eredményeink azt mutatják, hogy az őssejtek feldúsulása a sejtpopulációban csaknem olyan hatékony MACS-szel (79,53 \pm $5,78 \%)$, mint FACS-szel $(88,27 \pm 3,70 \%)$, a mágneses válogatás hatékonysága nem szignifikánsan gyengébb a FACS-nél. Háromszor megismételt méréseink eredményei azt mutatják, hogy FACS technikával történt válogatás után a populációnövekedés szignifikánsan és jelentősen gyengébb, mint MACS-szel történő szeparálás után. Ezzel ellentétben a két módszer kombinálása nem hatékony, mert az így leválogatott sejtpopulációk már nagyon kicsik, és az általunk vizsgált időszak alatt nemhogy nem indult meg a növekedésük, hanem még 
csökkent is a populációk mérete. Összességében megállapítható, hogy a MACS hatékonyságában hasonló a FACS-hez, ám annál kíméletesebb módszer.

A mágneses válogatásból származó sejtek karakterizálása a-STRO-1, a-CD44 ellenanyagokkal bizonyította, hogy a válogatásból származó sejtek valóban őssejtek. Ezt megerősítette a sejtközötti állomány Alizarin Reddel történt festődése, ami azt mutatja, hogy a sejtközötti állományban megkezdődött a kalciumlerakódás, azaz a sejtek elindultak az osteoblast irányú differenciálódás útján. Eredményeink alapján megállapítható, hogy a MACS válogatás után kapott őssejt populáció alkalmas további kísérletek elvégzésére.

\section{Köszönetnyilvánítás}

A kutatómunka és az ahhoz szükséges infrastruktúra a TAMOP-4.2.2.A-11/1/KONV-2012-0036 projekt támogatásával valósult meg.

\section{Irodalom}

1. Avasthi S, Srivastava RN, Singh A, Srivastava M: Stem Cell: Past, Present and Future - A Review Article. IJMU 2008; 3: 22-30.

2. Bodger MP, Izaguirre CA, Blacklock HA, Hoffbrand AV: Surface antigenic determinants on human pluripotent and unipotent hematopoietic progenitor cells. Blood 1983; 61: 1006-1010.

3. Bojic S, Volarevic V, LJuJic B, Stojkovic M: Dental stem cells characteristics and potential. Histol Histopathol 2014; 29: 699-706.

4. Dziubińska $P$, Jaskólska M, Przyborowska $P$, Adamiak Z: Stem cells in dentistry - Review of literature. Pol J Vet Sci 2013; 16: 135-140.
5. Fong CY, Peh GSL, Gauthaman K, Bongso A: Separation of SSEA-4 and TRA-1-6a labelled undifferentiated human embryonic stem cells from a heterogeneous cell population using magnetic-activated cell sorting (MACS) and fluorescence-ativated cell sorting (FACS). Stem Cell Rev and Rep 2009; 5: 72-80.

6. GERASCHENKo BI: Choosing cell sorting option to study the fate of bystander cells: FACS or MACS? Cytometry A 2011; 79: 179-180.

7. Gronthos S, Mankani M, Brahim J, Robey PG, Shi S: Postnatal human dental pulp stem cells (DPSCs) in vitro and in vivo. Proc Natl Acad Sci U S A 2000; 97: 13625-13630.

8. HAECKEL, E: Anthropogenie. (3rd ed) Wilhelm Engelmann, Leipzig; 1877.

9. HAECKEL, E: Natürliche Schöpfungsgeschichte. Georg Reimer, Berlin; 1868.

10. Jo YY, Lee HJ, Kook SY, Choung HW, Park JY, Chung JH et al.: Isolation and characterization of postnatal stem cells from human dental tissues. Tissue Eng 2007; 13: 767-773.

11. Kádár K, Porcsalmy B, Király M, Molnár B, Jobbágy-Óvári G, SOMOGYI E ÉS MTSAI: Humán fogbél eredetű őssejtek izolálása, tenyésztése és jellemzése. Fogorv Sz 2009; 102: 175-181.

12. Kato K, RADBRUCH A: Isolation and Characterization of CD34+ $\mathrm{He}-$ matopoietic Stem Cells From Human Peripheral Blood by HighGradient Magnetic Cell Sorting. Cytometry 1993; 14: 384-392.

13. Király M, Porcsalmy B, Pataki A, Kádár K, Jelitai M, Molnár B et AL.: Simultaneous PKC and CAMP activation induces differentiation of human dental pulp stem cells into functionally active neurons. Neurochem Int 2009; 55: 323-332.

14. MORRISON SJ, ShaH NM, Anderson DJ: Regulatory Mechanisms in Stem Cell Biology. Cell 1997; 88: 287-298.

15. Rolf hJ, Kierdorf U, Kierdorf H, Schulz J, Seymour N, SchliePHAKE H ET AL.: Localization and characterization of STRO-1+ cells int he deer pedicle and regenerating antler. Plos ONE 2008; 3: e2064.

16. Valli H, Sukhwani M, Dovey SL, Peters KA, Donohue J, Castro CA ET AL.: Fluorescence- and magnetic-activated cell sorting strategies to isolate and enrich human spermatogonial stem cells. Fertil Steril 2014; 102: 566-580.

17. Zhu B, Murthy SK: Stem cell separation technologies. Curr Opin Chem Eng 2013; 2: 3-7.

\section{Kerényi F, Tarapcsák Sz, Hrubi E, Baráthné Szabó Á, Hegedüs V,} Balogh S, Bágyı K, Varga G, Hegedüs Cs

\section{Comparison of sorting of fluorescently and magnetically labelled dental pulp stem cells.}

Stem cells are present in many tissues, such as dental pulp. Stem cells can be easily isolated from dental pulp because third molars are often removed from patients. Stem cells could be separated from the tissue derived heterogeneous cell population. There are two main methods to separate a cell type from the other ones: the fluorescence activated cell sorting (FACS) and the magnetic activated cell sorting (MACS). The aim of this study was to compare these methods' effect on cell surviving and population growth after sorting on dental pulp cells. The anti-STRO-1 antibody was used as primary antibody to specifically label stem cells. Two secondary antibodies were used: magnetic or fluorescent labelled. We sorted the cells by MACS or by FACS or by combination of both (MACS-FACS). Our results show that the effectivity of MACS and FACS sorting are comparable while of MACS-FACS was significantly higher (MACS 79,53 $\pm 5,78 \%$, FACS $88,27 \pm 3,70 \%$, MACS-FACS $98,43 \pm 0,67 \%$ ). The cell surviving and the post-sorting population growth, on the contrary, are very different. The cell population is growing on first week after MACS but after FACS did not. Moreover, after MACSFACS, on first week the cell number of population decreased. Taken together, our results suggest to use MACS instead of FACS, at least in case of sorting dental pulp stem cells with anti-STRO-1 antibody.

Keywords: DPSC, FACS, MACS. 